\title{
Reviving American Higher Education: An Analysis and Blueprint for Action
}

\section{Gerson Moreno-Riaño}

Colleges and universities are some of the most important social institutions in America. These institutions have the privilege of educating large segments of future generations of Americans who will advance or undermine the American way of life that has been bequeathed to them. These same institutions also have the greatest longevity of any other institution Americans have created. Harvard University-the first American university-was established in 1636, one-hundred and forty years before the American Revolution. Before 1776, there were a total of eighteen universities in America, all of which are still in operation. The most current official estimates suggest that there are over 4,000 degree-granting colleges and universities in America spending over $\$ 600$ billion dollars educating close to twenty million students. America's colleges and universities are thus foundational sources of cultural influence based on their vast reach, extensive resources, educational purpose, and historical transcendence.

But there is trouble in American higher education. This essay focuses on the concerns related to the moral corruption of America's college students caused by a viral anti-intellectualism spreading throughout American higher education. This anti-intellectualism is manifested through an unexamined rejection of Western civilization's moral tradition and its embodiment in America's founding vision and principles, in conjunction with an unexamined embrace of the moral traditions of other civilizations as new foundational pillars for American society. This anti-intellectualism or lack of serious intellectual inquiry can lead to the advance of falsehoods masquerading as truth and knowledge. As John Cobb, Jr. writes:

Gerson Moreno-Riaño is President of Cornerstone University; president@cornerstone.edu. This piece was prepared as part of the National Association of Scholars' conference "Mapping Higher Education's Future After the Election," on November 12, 2020. 
The lack of attention to assumptions has left unexamined some metaphysical assumptions that force scholars to neglect evidence and to defend positions that are obviously false. This is the real situation, while the university continues to present itself to the world as the source of unbiased knowledge. It places its prestige in support of a particular worldview, one that is demonstrably false. It socializes the elite to accept this unhealthy mental climate. ${ }^{1}$

This anti-intellectualism has been well documented. ${ }^{2}$ And it should be noted that this anti-intellectualism is not just a mere academic squabble among academicians. The incomplete and incoherent views of reality as well as the falsehoods advanced by such anti-intellectualism in academia have terrifying real-world consequences given the influence of colleges and universities upon the moral education and formation of students and faculty. ${ }^{3}$ The groundwork for revolution has been laid in our anarchic, anti-American curricula for some time, and unless corrective measures are taken a revolutionary anarchic ethos may become all too common on America's college campuses and beyond, leading to an American society and culture unrecognizable to preceding generations. The last section of this paper introduces a high-level blueprint that can serve as an impetus for the reform and revival of American higher education.

\section{The Problem}

American colleges and universities have always positioned themselves as the bastions of knowledge and truth for the moral formation of their students. Regardless of intellectual debates surrounding the meaning of such terms, universities in America have never rejected their implicit commitment to moral formation. As Julie A. Reuben reminds us in her book, The Making of the Modern University, “Universities never renounced their traditional moral aims. Educators continued to believe that universities should prepare their students to live "properly' and contribute to the betterment of society."

1 John. B. Cobb, Jr. "The Anti-Intellectualism of the American University," Soundings: An Interdisciplinary Journal 98, no. 2 (2015): 218-232. While Cobb is addressing the anti-intellectualism of the modern research university paradigm, his observations are equally applicable to the anti-intellectualism under consideration in this essay.

2 As examples, refer to Helen Pluckrose and James A. Lindsey, Cynical Theories: How Activist Scholarship Made Everything about Race, Gender, and Identity_and Why This Harms Everybody (Durham: Pitchstone Publishing, 2020); Grant Cornwell, "Truth, Facts, and Liberal Education in a 'Post-Truth' Era," Inside Higher Education, Opinion Section, December 3, 2018.

3 "The Anti-Intellectualism of the American University," 232.

4 Julie A. Reuben, The Making of the Modern University (Chicago: University of Chicago Press, 1996), 268. 
American higher education is replete with illustrations concerning the commitment of colleges and universities to the imperative of moral formation. Consider, for example, the following abridged mission or vision statements of Harvard University, the University of Virginia, Arizona State University, and the Massachusetts Institute of Technology, to take just a sample (emphasis added):

- To educate the citizens and citizen-leaders for our society ... through [a] commitment to the transformative power of a liberal arts and sciences education.

- To serve ... the nation ... by developing responsible citizen leaders and professionals.

- A comprehensive public research university ... assuming fundamental responsibility for the economic, social, cultural and overall health of the communities it serves.

- [W]e seek to develop in each member of [our community] the ability and passion to work wisely, creatively, and effectively for the betterment of humankind.

Beyond the institutional commitments to research, scholarship, and diversity, it is clear that one of the most fundamental goals of American higher education is the moral formation of students, a formation that presupposes a commitment to a particular moral core. But one should ask whether this moral core actually provides a sound moral formation and education to America's students. Considering the $\$ 600$ billion investment in American higher education, what type of human beings are American colleges and universities cultivating? To focus this inquiry, one should consider the type of American human being universities are cultivating since America's colleges and universities are American institutions created to advance and sustain the wellbeing of the nation-of the United States of America.

To start, the sound moral formation of any human being involves a commitment to a worldview that accurately and correctly defines the true, beautiful, and good. Consequently, sound moral formation and education is sound to the degree that it corresponds to what is genuinely true, beautiful, and good. However, not all moral formation and education is true, beautiful, and good. Examples abound of moral formation and education that lead to the creation of cultures with wicked practices and the cultivation of human beings that think, 
feel, and act wickedly. That which is ultimately and metaphysically true, beautiful, and good is the universal standard that rightly measures the soundness of moral formation and education. From truth, beauty, and goodness flow the virtues that one could deem necessary for the proper formation of all human beings and, by extension, an American human being situated in a liberal, representative democracy. William Galston offers insights into these virtues in Civic Education in the Liberal State:

Some of the virtues needed to sustain the liberal state are requisites of every political community: the willingness to fight on behalf of one's country; the settled disposition to obey the law; and loyalty-the developed capacity to understand, to accept, and to act on the core principles of one's society. Some of the individual traits are specific to liberal societyindependence, tolerance, and respect for individual excellences and accomplishments . . . For citizens, the disposition to respect the rights of others, the capacity to evaluate the talents, character, and performance of public officials, and the ability to moderate public desires in the face of public limits are essential. ${ }^{5}$

The virtues requisite for a functioning constitutional republic are necessarily derived from a foundational commitment to educate toward the true, beautiful, and good. Dedication to these virtues founded in Truth is the lifeblood of a civil, democratic society.

This notion runs against the grain of many American academics who believe that there is no universal truth and, therefore, that truth is a function of human experience and not a fundamental, metaphysical characteristic outside of human experience to which the latter is accountable. This perspective was heralded in America through the philosophy known as pragmatism and their primary advocates William James and John Dewey. Pragmatism and its heralds rejected the notion of a fixed truth rooted in an ultimate reality and being outside of human experience. As such, truth was a blind dogma serving as an obstacle to human creativity, self-discovery, and progress. Truth had to be set free from fictional ideals so that it could in turn set humanity free to achieve full self-realization and self-actualization. As Dewey writes,

5 William Galston, Civic Education in the Liberal State, ed. Amilie Oksenberg Rorty (New York, NY: Routledge, 1998), 473. 
Turning from such rather superficial misunderstandings, we find, I think, the chief obstacle to the reception of this notion of truth is an inheritance from the classic tradition that has become so deeply engrained in men's minds. In just the degree in which existence is divided into two realms, a higher one of perfect being and a lower one of seeming, phenomenal, deficient reality, truth and falsity are thought of as fixed, ready-made static properties of things themselves ... It makes claims to Reality which it cannot substantiate. This view is radically challenged by the pragmatic conception of truth, and the impossibility of reconciliation or compromise is, I think, the cause of the shock occasioned by the newer theory. ${ }^{6}$

The rejection of a transcendent and universal true, beautiful, and good led to the relegation of the true, beautiful, and good to mere creations of human experience to be changed as desired or demanded. Absent universal truth, beauty and goodness, the ultimate reality is a protean human experience that requires the freedom and power to act upon it and to change it. As William James writes in Pragmatism:

A pragmatist turns his back resolutely and once for all upon a lot of inveterate habits dear to professional philosophers. He turns away from abstraction and insufficiency, from verbal solutions, from bad a priori reasons, from fixed principles, closed systems, and pretended absolutes and origins. He turns towards concreteness and adequacy, towards facts, towards action, and towards power. ${ }^{7}$

Pragmatism has had a profound influence on American intellectual life. As a philosophy, it informed the thought of Supreme Court Justice Oliver Wendell Holmes, Jr. and American jurisprudence thereafter. Holmes famously declared that the "life of the law has not been logic: it has been experience," ${ }^{8}$ that "absolute truth is a mirage," ${ }^{9}$ and that he saw "not the slightest reason for believing that our reason and our truth are cosmic ultimates or anything more than our

6 John Dewey. Reconstruction in Philosophy (New York: Henry Holt \& Company, 1920), 159.

7 William James, Pragmatism - A New Name for Some Old Ways of Thinking, Lecture II: What Pragmatism Means, The Project Gutenberg E-Book, 2004, https://www.gutenberg.org/files/5116/5116-h/5116-h.htm.

8 In Common Law (1881).

9 Holmes-Laski Letters, 1916-1935, ed. Mark DeWolfe Howe, (Cambridge: Harvard University Press, 1953) II, 1125. 
own flammantia moenia."10 The pervasiveness of pragmatism has been a driving force in all levels of American education and teacher preparation ever since the publication of John Dewey's Democracy and Education (1916). And its influence on liberal education and undergraduate curricula is clearly documented both in the scholarly literature ${ }^{11}$ as well as through a thorough exploration of the publications and initiatives of the Association of American Colleges \& Universities, which considers liberal education as a "living tradition whose inherent flexibility and responsiveness contribute to its ongoing vitality and relevance." ${ }^{12}$ There is no doubt that the current revolutionary ethos in American higher education and its students is deeply rooted both in pragmatism's rejection of a universally existing truth and its acceptance of the malleability of reality through power, action, and change. American colleges and universities that morally form and educate their students within this pragmatic context subvert not only their moral and educational mission but also their purported support for the health of American democracy.

What does this subversion look like? For answers, one should begin with The Vanishing West, one of the most comprehensive reports on the moral core of American higher education, published by the National Association of Scholars in 2011. In universities across the country, this moral core has often been embedded in university core courses that explore Western Civilization and American history. The Vanishing West reports that in the early 1960's ten of the "top" fifty U.S. universities mandated a Western Civilization course; by 2011, however, none of these schools and only one of the top seventy-five public universities mandated such a course. The report also discovered that American history courses had virtually disappeared from general education requirements. The authors concluded:

Clearly, many of those who will eventually assume positions of opinion leadership in our society as teachers in our schools, or as participants in public life, are no longer learning about their civilization's great story, its triumphs, its vicissitudes, and its singular role in transforming the human

10 lbid. 706.

11 See, for example, Bruce A. Kimball, Robert Orrill. The Condition of American Liberal Education: Pragmatism and $a$ Changing Tradition, College Entrance Examination Board, 1995.

12 Association of American Colleges \& Universities, What Liberal Education Looks Like, Washington, DC, 2000, 5, https://portal.criticalimpact.com/user/25043/image/whatlibedlookslike.pdf (accessed November 11, 2020). 
condition. What is the future of a civilization whose heirs have largely become blinded to its history ${ }^{13}$

Apparently, historical blindness had become an educational condition of the moral core of American higher education. This historical blindness was, however, selective in nature. The report also noted that world history was in the "process of superseding Western history as the preferred non-American history survey course, and even as a scholarly specialization." ${ }^{14}$ If it is true that a society studies what it values, then American colleges and universities were the first American institutions to de-value their own history and civilizational foundations in pursuit of a more fitting history and tradition.

It is important to emphasize that there is more at stake than just the de-valuing of the received moral tradition of the West and America and its substitution by other moral traditions. Western Civilization and its embodiment in America are both rooted in the very things American pragmatists and many American intellectuals and academics deny: a commitment to truth, beauty, and goodness rooted in the reality, existence, and loving supernatural and natural revelation of the Judeo-Christian God. This is a commitment to a universal Truth that transcends human experience, to the principle that humanity possesses rights and freedoms that also transcend human experience, and to a transcendent understanding of justice positing that humanity can be held accountable to God, Truth, and a universal moral code.

Since the publication of The Vanishing West, the condition of the moral core of American higher education has worsened. Not only has the selective historical blindness toward American history and Western Civilization continued to be pervasive due to their replacement by a cornucopia of course electives ${ }^{15}$ but this selective historical blindness has been replaced with an aggressive, if not militaristic, imposition of a new moral core educating students in an alternative moral tradition-revolutionary oppression studies. This imposition has been brilliantly expounded by Stanley Kurtz in The Lost History of Western Civilization, a 2020 report from the National Association of Scholars. ${ }^{16}$

13 Glenn Ricketts, Peter W. Wood, Stephen H. Balch, Ashley Thorne, The Vanishing West: The Disappearance of Western Civilization from the American Undergraduate Curriculum (New York: National Association of Scholars, 2011), v.

14 Ibid., 14.

15 The "What Will They Learn?" project of the American Council of Trustees and Alumni has documented the continual and pervasive erosion of the general education core curriculum among American colleges and universities since 2009.

16 Stanley Kurtz, The Lost History of Western Civilization (New York: National Association of Scholars, 2020). 
Kurtz details not only the evisceration of the received Western tradition in American academia, particularly at Stanford University, but also the installation of an educational ethos and core that presuppose a socially contingent reality, not an objective reality. While The Vanishing West alerted Americans concerning the replacement of Western Civilization and American history courses by World history courses and loose general education requirements, another more corrosive replacement was simultaneously occurring. First, the received tradition of Western Civilization and American history began to be defined as systemically and thoroughly oppressive, racist, and evil with no redeeming value. Second, this received tradition had to be replaced with other moral traditions that sought the complete destruction of the West and America so that a new space for a more humane social order could be created. These redefinitions and replacements have been occurring in American higher education for many years without any significant intellectual self-assessment on the part of their advocates. To ask these advocates a question or suggest that a responsible and thorough self-assessment is needed amounts to oppression and racism. This is the high mark of anti-intellectualism in American higher education.

It can be of no surprise that as this new anti-intellectual moral core has drifted further and further from the true, beautiful, and good, the teaching of virtues has become increasingly absent from America's most elite institutions, replaced with courses antithetical to freedom, tolerance, and civil discourse. During the 2020 fall semester, Washington \& Lee University, one of America's oldest and most distinguished universities, offered a freshman class entitled, Writing Seminar for First-Years: How to Overthrow the State, which "places each student at the head of a popular revolutionary movement aiming to overthrow a sitting government and forge a better society" and requires a "Manifesto" or an essay "rewriting history." Yale University has eliminated courses in art history and English literature to "decolonize" degree requirements with other colleges and universities offering courses in "The Power of Whiteness" (Providence College), “Racial Capitalism” (Williams College), "Queering God” (Swarthmore College) and “How to Stage a Revolution" (MIT). And the Walter Cronkite School of Journalism at Arizona State University, America's most "innovative university" according to U.S. News \& World Report, removed its dean and the work of several of its journalists simply for publishing content deemed too friendly to the police, the enforcement arm of a "corrupt" system. 
There are numerous other examples across the American higher education landscape illustrating both the marginalization and elimination of the Western and American moral tradition. This radical shift in the moral education of America's college students has resulted in the fact that America's universities-not those in North Korea or the People's Republic of China-have become the training ground for home-grown domestic revolutionaries seeking to end America. America's college classrooms and campuses now resemble engineering laboratories for revolution where teaching and campus life focuses on transforming students into radical, violent activists. These "learning spaces" are the breeding grounds of intolerance where the other-any other-who does not pledge absolute allegiance to the emerging revolutionary ethos is demonized, canceled, or destroyed. Colleges are subject to this same insidious ethos with an abolitionist movement afoot seeking to erase universities along with police and prisons. ${ }^{17}$

\section{A Blueprint for Reform and Revival}

Reviving American higher education will require reforms that address the anti-intellectual moral crisis of academia through both moral correction and meaningful accountability. Two simple and related initiatives should inform a new reform movement to revive American higher education: 1) the reintegration of the true, beautiful, and good within a context of pervasive and consistent open inquiry; and 2) an incentivized framework of transparency and accountability that provides or removes funding from colleges and universities that fail to sustain and protect this reintegration. Both of these efforts are a response to the anti-intellectualism that has infected America's institutions of higher learning and to the call "to restore and recover the history we've abandoned under an avalanche of deconstructive skepticism." 18

The reintegration of the true, beautiful, and good (hereafter “Truth") as an educational outcome of general education and campus life education grounded upon a demonstrable commitment to open inquiry is central to correcting and healing the maladies that currently infect American higher education. As argued earlier, the very existence of an American constitutional republic-upon

17 The Abolition University movement seeks to abolish the contemporary institution of the university. See Abolitionist University Studies: An Invitation at https://abolition.university/invitation as well as information on this movement's conference held at Duke University on October 11-12, 2019, https://abolition. university/conference/.

18 The Lost History of Western Civilization, 144. 
which American universities are dependent-is contingent upon the principles that arise from a Western commitment to the reality of the transcendent Truth. This reintegration presupposes that Truth and knowledge are not socially contingent, are knowable universal objects of reality, are essential pillars of the moral education to which colleges and universities are openly committed and are foundational to a flourishing nation and world. This in practice would entail general and campus life educational curricula that fairly and openly consider the breadth and depth of approaches to Truth and knowledge while not being fixated on the virtuousness of oppressed traditions and the evils of the oppressor tradition, the West, and America.

To resituate general and campus education curricula would also entail an approach that grounds human evil as a universal reality infecting all humans, cultures, and civilizations everywhere, and not just a particular group, skin color, culture, or civilization. Just as Truth and knowledge are ascertainable objects worthy of pursuit, so too is evil ascertainable and an object worthy of identification and rejection. This reintegration must also entail a comprehensive requirement for all American colleges and universities to ensure that all of their students are thoroughly and fairly exposed to the enduring greatness and the failings of Western Civilization and American history-along with an honest study of other alternatives. American higher education would begin to be radically transformed for the good of the nation if this reintegration were consistently implemented and assessed.

This reintegration would also require a framework of transparency and accountability to support, incentivize, and ensure that American institutions of higher education implement, sustain, and protect related educational outcomes. To begin, the outcome of this framework should be the establishment, nurture, and protection of a true culture of open inquiry on the campuses of American colleges and universities. The marginalization, demonization, and elimination of the received moral tradition of Western Civilization and the United States cannot be allowed in American colleges and universities that claim tax-exempt status due to their educational purposes. Truth, freedom, and open inquiry are essential preconditions for moral formation and education. If American colleges and universities reject the pursuit of Truth and fostering open inquiry, then such institutions are no longer educational in nature and their tax-exempt status should be reclassified at both state and federal levels. 
Transparency in higher education can significantly shift the direction and viability of universities. It introduces a level of market discipline to educational institutions that too often operate in a vacuum. As a case in point consider the potential effect of transparency measures to assess the attainment of gainful employment of graduates of institutions of higher education in America. The mere transparency data requirement and a school's performance related to the measure appears to be correlated to the propensity of a program or college to close. ${ }^{19}$ Similarly, American colleges and universities should be required annually and publicly to report on an Education, American History, and Freedom measure that would assess the level to which any college or university integrates a comprehensive exploration of Truth and a balanced exploration of the WesternAmerican tradition as educational outcomes, including the pervasiveness and consistent integration of free and open inquiry throughout a college campus. The creation of such a measure requires much thought and collaboration along with an exploration of measures already in existence that attempt to gauge a society's freedom and democratic health. ${ }^{20}$ All colleges and universities should be held accountable at both the institutional and programmatic level with potential rewards and penalties as it relates to federal and state tax subsidies, student loan eligibility, research grant funding, tax-exempt status, and accreditation recognition.

The suggested framework of transparency and accountability should also involve the revitalization and use of accrediting agencies as instruments of a vibrant civic society that hold institutions of higher education accountable. Many academics often hold accrediting agencies at arms-length and consider them anathema to the true purposes of higher education. But such prejudice should be rejected in favor of a more reform-minded approach, as such agencies can be used to drive institutional revival. This is exactly the same approach that the Human Rights Campaign has advanced in its Blueprint for Positive Change 2020-a comprehensive list of eighty-five policy recommendations for the Joe Biden presidential administration-with the exception that the focus is solely on advancing the interests of the LGBTQ community and eliminating

19 Robert Kelchen, Zhuoyao Liu, "Did Gainful Employment Regulations Result in College and Program Closures? An Empirical Analysis." Working Paper, 2019, https://kelchenoneducation.files.wordpress. com/2019/11/kelchen_liu_nov19.pdf.

20 See, for example, the CATO Institute's Human Freedom Index and the U.S. Department of State's measures for religious freedom and democracy. 
the freedom and accreditation of religious institutions of higher education. The authors of Blueprint argue the following:

Language regarding accreditation of religious institutions of higher education in the Higher Education Opportunity Act could be interpreted to require accrediting bodies to accredit religious institutions that discriminate or that do not meet science-based curricula standards. The Department of Education should issue a regulation clarifying that this provision, which requires accreditation agencies to "respect the stated mission" of religious institutions, does not require the accreditation of religious institutions that do not meet neutral accreditation standards including nondiscrimination policies and scientific curriculum requirements. ${ }^{21}$

If one cares deeply about the current state of American higher education and its moral bankruptcy, then accrediting agencies are indispensable mechanisms of reform when used appropriately.

How could accrediting agencies join the clarion call for a revival of American higher education? It should be recalled that the accreditation of a college, university, or academic program signals a basic modicum of quality based upon the principles of accreditation of a regional or specialized accreditor. To these principles of accreditation should be added comprehensive accreditation standards that require colleges, universities, and programs to demonstrate an institution's performance in the Education, American History, and Freedom measure briefly discussed earlier. Further, accrediting bodies must ensure that colleges and universities uphold their own mission statements. This is a critical aspect of the granting of accreditation to any higher educational institution. Regional accreditors such as the Southern Association of Colleges and Schools Commission on Colleges and the Higher Learning Commission situate mission integrity as a comprehensive requirement without which an institution cannot be accredited. Accrediting agencies require American colleges and universities to be grounded in a mission that is "comprehensive," "appropriate for higher

21 See Blueprint for Positive Change 2020, 8, https://hrc-prod-requests.s3-us-west-2.amazonaws.com/ Blueprint-2020.pdf?mtime=20201110185320\&focal=none. 
education" addressing both "teaching and learning," 22 that "guides the institution's operations," and that "demonstrates commitment to the public good."23

Consider, for example, the mission statements and objectives of the following accredited universities all of which are expected to advance missions that are fully educational and serve the public good. And yet each of these institutions are also guilty of rejecting the Western-American tradition while simultaneously indoctrinating students toward revolutionary action in curricula and campus life initiatives:

Stanford University: To qualify its students for personal success, and direct usefulness in life; to promote the public welfare by exercising an influence on behalf of humanity and civilization, teaching the blessings of liberty regulated by law, and inculcating love and reverence for the great principles of government as derived from the inalienable rights of man to life, liberty, and the pursuit of happiness. ${ }^{24}$

Washington \& Lee: To provide a liberal arts education that develops students' capacity to think freely, critically, and humanely and to conduct themselves with honor, integrity, and civility. ${ }^{25}$

Providence College: A Catholic, Dominican, liberal arts institution of higher education and a community committed to academic excellence in pursuit of the truth, growth in virtue, and service of God and neighbor. ${ }^{26}$

Accrediting organizations must hold American colleges and universities accountable to their own institutional missions and to fully uphold the principles of accreditation which are said to protect and promote educational quality for the public good.

Accrediting bodies as civic organizations within civil society can have a profound influence on the direction and quality of American higher education through incentives and sanctions related to accreditation, reaccreditation, and probationary decisions affecting an institution's reputation and viability in the higher education marketplace. As difficult as it may appear for these types of reforms to be implemented, it is crucial that an aggressive and comprehensive reform effort commence, and that pessimistic inertia not become that to which

22 These requirements are delineated in "The Principles of Accreditation" manual of the Southern Association for Colleges and Schools Commission on Colleges.

23 These requirements are delineated in "The Criteria for Accreditation of the Higher Learning Commission."

24 See Stanford's mission at https://exploredegrees.stanford.edu/stanfordsmission.

25 See Washington and Lee's mission at https://www.wlu.edu/the-w-l-story/mission-and-vision.

26 See Providence College mission at https://about.providence.edu/mission. 
one defaults. The situation is dire but not all is lost. As Stanley Kurtz reminds us in the closing pages of The Lost History of Western Civilization, "it's still not too late to return to Western civilization and the common national culture that a common heritage informs. We can return to the West because we've never really left it." ${ }^{27}$ It is incumbent upon any American that cares deeply about the relationship of education and the wellbeing of the American republic courageously to support and advance a collaborative reform effort to redirect and revive American higher education for the foreseeable future. Our universities and colleges, our students, and our democracy need this renewal now more than ever.

27 The Lost History of Western Civilization, 144. 